\title{
Sulphate reduction in the root zone of the seagrass Zostera noltii on the intertidal flats of a coastal lagoon (Arcachon, France)
}

\author{
Mai Faurschou Isaksen, Kai Finster* \\ Institute of Biological Sciences, Department of Microbial Ecology, University of Aarhus, DK-8000 Aarhus, Denmark
}

\begin{abstract}
Rates of sulphate reduction were determined in sediments from the eutrophic Bay of Arcachon, France. A comparison was made between sediment overgrown with the eelgrass Zostera noltii and unvegetated sediment. Rates of sulphate reduction were about twice as high in the root zone from

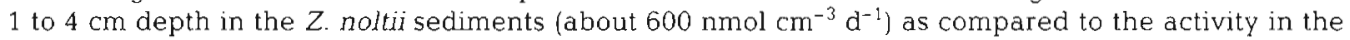
equivalent layer of the unvegetated sediment. The sulphate reduction in the root zone was not stimulated by light, which in other studies with other submersed macrophytes has been shown to promote sulphate reduction due to heightened excretion of organic molecules. Furthermore, in a field experiment, we were not able to detect any diurnal variation in the activity within the root zone. The stimulation of sulphate reduction by the presence of the $Z$. noltii was most likely due to degradation of leaf and root fragments which were found mixed into the sediment. Incubation times with radioactive sulphate had to be kept very short (preferably $15 \mathrm{~min}$ ) to avoid a substantial reoxidation of sulphide and hence an underestimation of the rate of sulphate reduction.
\end{abstract}

KEY WORDS: Diurnal - Reoxidation - Root exudation - Excretion Oxygen - Photosynthesis - Regulation - Submersed macrophytes - Sulphate-reducing bacteria $\cdot$ Sulphide

\section{INTRODUCTION}

Seagrass meadows are among the most productive aquatic ecosystems and have been subject to intensive ecological investigations in the past (reviewed in Pollard et al. 1993). It has been suggested that the plants, by root excretion of organic compounds and oxygen, may have considerable impact on the activity and structure of the microbial community in the sediment (Smith et al. 1984, Moriarty et al. 1985, Moriarty et al. 1986. Caffrey \& Kemp 1990, Pollard \& Moriarty 1991), and several investigations have demonstrated a diurnal variation in the plant-microbial community interactions (Oremland \& Taylor 1977, Caffrey \& Kemp 1991, Koepfler et al. 1993). where sulphate reduction has also been found to vary through the day and night (Pollard \& Moriarty 1991).

•Addressee for correspondence. E-mail: kai@bio.aau.dk
The loss of oxygen and organic compounds from the roots may have an influence on sulphate reduction. The presence of oxygen in the rhizosphere will enable aerobic bacteria to compete with sulphate reducers for organic substrates and consequently decrease rates of sulphate reduction. Oxygen can also oxidise reduced sulphur compounds, or it can oxidise ferrous iron and reduced manganese compounds which then subsequently can oxidise sulphide, and sulphate reduction measurements based on the accumulation rate of radiolabelled sulphide will then be more or less underestimated depending on the length of the incubation period (Jørgensen 1994, Moeslund et al. 1994). The organic exudates probably constitute a pool of easily degradable components. Blackburn et al. (1994) argued in favour of such a pool, as they observed a pronounced decrease in the accumulation of radiolabelled sulphide after an approximately 7 to $8 \mathrm{~h}$ incubation of oligotrophic sediment covered with the tropical submersed macrophyte Halodule sp. 
Sulphate reduction in seagrass beds has mainly been investigated in tropical or subtropical subtidal areas (Moriarty et al. 1985, Pollard \& Moriarty 1991, Blackburn et al. 1994) and to our knowledge no studies have been made on the influence of the temperate seagrasses (in our study the intertidal Zostera noltii) on sulphate reduction.

The purpose of our investigation was to study in detail sulphate reduction in the root zone, focusing on the following questions:

(1) Are the measured sulphate reduction rates affected by the duration of the incubation due to a possible reoxidation of sulphide caused by oxygen-excreting roots (Sand-Jensen et al. 1982, Caffrey \& Kemp 1991)?

(2) Will the sulphate reduction decrease in the dark, due to a decrease in availability of easily degradable organic matter when there is no photosynthesis (Smith et di. 1984, Moniarty et al. 1985, Pollard \& Moriarty $1991)$ ?

(3) Is the pattern of sulphate reduction rates obtained in laboratory experiments representative of in situ conditions where changes in temperature, oxygen tension, light, and tidal impact may be difficult to simulate?

\section{MATERIAL AND METHODS}

Study area. The study was conducted in the Basin of Arcachon $\left(44^{\circ} 40^{\prime} \mathrm{N}, 1^{\circ} 10^{\prime} \mathrm{W}\right)$ near Bordeaux, on the southwest coast of France. The total area of the coastal lagoon is $155 \mathrm{~km}^{2}$, but only $40 \mathrm{~km}^{2}$ are subtidal.

Sediment cores were sampled in May and September 1994 from sampling Stn B during the third and the fourth joint campaign of the CLEAN project (Coastal Lagoon Eutrophication and ANaerobic processes) sponsored by the European Union 'Environment' programme. The investigated site is located in the inner part of the Basin of Arcachon close to the shore and near the banks of a small channel draining the flat. In the following, the Zostera noltii-covered part of the station is referred to as $\mathrm{Stn} B \mathrm{BZ}$, while the area free of Z. noltir is called Stn B.

At high tide, the water level at Stns B and BZ varied between 30 and $150 \mathrm{~cm}$ and the stations were above the water level for 10 to $12 \mathrm{~h}$ daily (the hydrobiological parameters of the lagoon are described in Robert et al. 1987). However, while the sediment at Stn B was directly exposed to air at low tide, the sediment at Stn BZ was covered by a 0.5 to $1 \mathrm{~cm}$ thick layer of water that was retained by the collapsed canopy. Apart from small areas along the draining channels, the sediment was densely covered by Zostera noltii with roots penetrating 3 to $4 \mathrm{~cm}$ into the sediment. Root and leaf biomasses in the area have been determined to be 70 to $100 \mathrm{~g}$ dry weight $(\mathrm{dw}) \mathrm{m}^{-2}$ and 70 to $160 \mathrm{~g} \mathrm{dw} \mathrm{m}^{-2}$, respectively (Auby 1991). The sediment surface of both sites was inhabited by large numbers of mud snails (Hydrobia sp.)

Sampling and incubation. Laboratory experiments: A series of sediment cores was collected in 1 patch with and in 1 patch without Zostera noltii at the start of Expts 1 and 2 (see below); samples for Expt 3 were collected twice, as light and dark cycle incubations were carried out separately due to the limited size of the incubation aquarium. Cores were taken at low tide with Plexiglas tubes $190 \mathrm{~mm}$ o.d., $87 \mathrm{~mm}$ i.d., $200 \mathrm{~mm}$ long). Care was taken not to push leaves into the sediment during sampling. The tubes contained 4 vertical. rows of silicone-rubber filled injection ports separated by an angle of $90^{\circ}$. The vertical distance between the ports in each row was $10 \mathrm{~mm}$. By this arrangement, we ensured a gond distribution of the injected radiotracers.

After sampling, the cores were stored in dark containers held near the in situ temperature and quickly driven to the laboratory. Before incubation in an aquarium held at the in situ temperature $\left(19^{\circ} \mathrm{C}\right)$, the sediment surface was pushed up so that it was flush with the upper edge of the Plexiglas tube. The sediment surface was covered by $10 \mathrm{~cm}$ of water during the incubation, allowing Zostera noltii leaves to move freely. The position of each core in the aquarium was random to avoid systematic errors. The aquarium was filled with sea water taken from in front of the marine station. (31\% salinity). Water in the aquarium was mixed by bubbling with. air. Two $500 \mathrm{~W}$ halogen lamps served as light sources. The irradiance (400 to $700 \mathrm{~nm}$ range) at the sediment surface varied between 150 and $220 \mu \mathrm{E}$ $\mathrm{m}^{-2} \mathrm{~s}^{-1}$ among the different cores, depending on their position in the aquarium. This light intensity was in good agreement with the intensity measured in the field around noon under an equivalent cover of water (see below)

Before starting the experiments, cores for experiments in the light were preincubated in the dark for $12 \mathrm{~h}$ and cores for dark experiments were preincubated in the light for $12 \mathrm{~h}$. The following 3 laboratory experiments were conducted:

Expt 1. A possible effect of the duration of the illumination period on sulphate reduction rate (SRR) was studied by sampling 5 cores with and 3 without Zostera noltii for each incubation period $(0.25,1,5$, and $10 \mathrm{~h})$.

Expt 2: The effect of duration of dark incubation on SRR was performed using 4 cores with and 2 without Zostera noltii for each incubation period $(1,2,4,8,14$, 22 and $4.8 \mathrm{~h}$ ).

Expt 3: The diurnal variation in SRR was studied by making determinations at different time points during 
an artificial $12 \mathrm{~h}$ light cycle and $12 \mathrm{~h}$ dark cycle. SRR measurements were made every $3 \mathrm{~h}$ by ${ }^{35} \mathrm{SO}_{4}{ }^{2-}$ incubation of 5 cores with and 3 without Zostera noltii for half an hour. The first light incubation was made immediately after the light period was started, and similarly, for the first dark incubation was made immediately after the dark peroid was started.

In situ experiments: In order to compare data obtained in the laboratory with data collected in the field, the experiments described below were carried out at Stn BZ. In the morning (08:00 h) at low tide, 5 Plexiglas tubes (described above) were carefully pushed into the sediment. For all in situ incubations, ${ }^{35} \mathrm{SO}_{4}{ }^{2-}$ was injected into each sediment core from above with a syringe equipped with a $10 \mathrm{~cm}$ long needle, and after $1 \mathrm{~h}$ of incubation the cores were withdrawn and the incubations were stopped. A second series of measurements was carried out in the middle of the day $(14: 00 \mathrm{~h})$, when the seagrass meadow was covered by $50 \mathrm{~cm}$ of water. The water cover made direct injection into the sediment impossible, and cores were therefore withdrawn prior to injection and replaced in the sediment. A third series of measurements was made in the late afternoon (18:00 h) at low tide.

A simultaneous dark incubation was carried out by covering $2 \mathrm{~m}^{2}$ of seagrass meadow with a thin lightimpermeable aluminium sheet from the morning and until the end of the experiment. Incubations for sulphate reduction rates in the dark under the aluminium were started at 18:00 h using the same injection technique as described above. The aluminium sheet was only loosely fastened to the sediment to avoid an extreme change of physical and chemical conditions.

Sulphate reduction rates. Sulphate reduction rates were determined by the radiotracer method (Jorgensen 1977, Fossing \& Jørgensen 1989). Carrier-free ${ }^{35} \mathrm{SO}_{4}{ }^{2-}\left(15 \mu \mathrm{l}_{i}<0.1 \mathrm{nmol}\right.$ of ${ }^{35} \mathrm{SO}_{4}{ }^{2-} ; 150 \mathrm{kBq}$; Isotope Laboratory, Risø, Denmark) diluted in sea water was injected through the side ports into the sediment core, giving an average activity of $10 \mathrm{kBq} \mathrm{\textrm {cm } ^ { - 3 }}$

At the end of the incubation, the upper $2 \mathrm{~cm}$ of the cores were cut into 2 sections of $1 \mathrm{~cm}$ each, and the zone from 2 to $6 \mathrm{~cm}$ was sectioned into 2 slices of $2 \mathrm{~cm}$ each. The sediment was transferred to plastic bottles containing 5 or $10 \mathrm{ml}$ of a $5 \%$ (wt/wt) Zn-acetate solution for 1 or $2 \mathrm{~cm}$ sections, respectively, to stop biological activity and to preserve sulphide. The plastic bottles were closed with a screw cap and shaken vigorously to mix the sediment with the Zn-acetate solution. The weight of the sediment slice was determined and a subsampie for sulphate analysis was transferred to a plastic screw-capped centrifuge tube and stored in a freezer until further processing.
The formation of $\mathrm{H}_{2}{ }^{35} \mathrm{~S}$ was determined by the 1-step $\mathrm{Cr}^{2+}$ distillation method (Fossing \& Jørgensen 1989). Sulphate reduction rates (SRR) were calculated from the following equation:

$$
\mathrm{SRR}=\frac{\left(\mathrm{SO}_{4}{ }^{2-}\right) \times\left(\mathrm{H}_{2}{ }^{35} \mathrm{~S}\right) \times 1.06}{\left(\left({ }^{35} \mathrm{SO}_{4}{ }^{2-}\right)+\left(\mathrm{H}_{2}{ }^{35} \mathrm{~S}\right)\right) \times T}
$$

where $\left(\mathrm{SO}_{4}{ }^{2-}\right)=$ sulphate concentration; $\left(\mathrm{H}_{2}{ }^{33} \mathrm{~S}\right)=$ total counts of the radiolabelled sulphide ${ }_{i}\left({ }^{35} \mathrm{SO}_{4}{ }^{2-}\right)=$ total counts in the radiolabelled sulphate; $T=$ incubation time; and 1.06 is the $\mathrm{S}^{32} / \mathrm{S}^{35}$ ratio (Sorokin 1962). SRR is expressed in nmol $\mathrm{cm}^{-3} \mathrm{~d}^{-1}$.

Physical characteristics. Porosity and specific density of sediments were determined on $10 \mathrm{~cm}^{3}$ triplicate samples from each $1 \mathrm{~cm}$ depth interval down to $10 \mathrm{~cm}$. The porosity was determined from the weight loss by drying at $105^{\circ} \mathrm{C}$ for $12 \mathrm{~h}$. Profiles of redox potential and $\mathrm{pH}$ in the sediment were obtained by carefully pushing a needle $E_{h}$ electrode and a glass $\mathrm{pH}$ electrode (Radiometer), respectively, into the sediment, with readings on a portable voltmeter being taken for each $1 \mathrm{~cm}$ interval.

Chemical determination. Sulphate in pore water: Pore water was obtained by centrifugation of $\mathrm{Zn}$ acetate-preserved sediment samples taken during the radiotracer experiment. Sulphate was determined by suppressed ion chromatography with a Sykam (Gilching, Germany) ion-chromatography system, consisting of a pump (model S1110), a column oven (model S4110), a conductivity detector (S3110) and an autosampler (model 851-AS; Jasco, Tokyo, Japan). The stainless-steel column ( 4 by $125 \mathrm{~mm}$; LCA A09, Sykam) was kept at $60^{\circ} \mathrm{C}$. The eluent contained $\mathrm{Na}_{2} \mathrm{CO}_{3}$ (7.5 mM), ethanol ( $5 \%, \mathrm{vol} / \mathrm{vol})$, and 4-hydroxy-benzonitril (50 $\mathrm{mg} \mathrm{l}^{-1}$ ). The flow rate was $2 \mathrm{ml} \mathrm{min}^{-1}$ and the analysis time was 5 min.

Sediment: The content of organic carbon and total nitrogen was determined on dried and homogenised sediment samples after treatment with $\mathrm{H}_{2} \mathrm{SO}_{3}$ to remove inorganic carbon. The samples $(40$ to $50 \mathrm{mg}$ ) were processed in an $\mathrm{HCN}$ analyser (Carlo Erba $\mathrm{Na}$ 1500 nitrogen analyser; Strumentazione, Rodano, Milano, Italy).

The content of roots and leaves was determined in $1 \mathrm{~cm}$ sediment slices $\left(60 \mathrm{~cm}^{3}\right)$. The sediment slices were washed on a sieve (mesh size $1 \mathrm{~mm}$ ), and the retained material, which was a mixture of roots, leaves, and shells, was transferred to plastic cups and dried at $105^{\circ} \mathrm{C}$ for $12 \mathrm{~h}$. Shells and larger sediment particles were removed, and the sample was washed with a solution of $\mathrm{HCl}$ to remove smaller particles of carbonates. The weight of the remaining organic part of the samples (= roots and leaves) was subsequently determined after drying for $48 \mathrm{~h}$ at $70^{\circ} \mathrm{C}$. 


\section{RESULTS}

\section{Field observations}

Sediment from Stns B and BZ consisted of silty material and was rich in detritus and organic matter. The sediment surface was inhabited by large numbers of mud snails. Except for a thin brown layer at the top $(<0.5 \mathrm{~cm})$, the sediment from Stn B was black throughout the core and released a strong odour of hydrogen sulphide. The surface was locally coated by small patches of purple sulphur and colourless sulphur bacteria. Sediment from Stn BZ, in contrast, was grey and did not smell of hydrogen sulphide. These observations also coincided with differences in redox potentials and pH profiles (Table 1). At Stn B, the redox potential decreased very rapidly with depth from $+116 \mathrm{mV}$ in the upper centimetre to $<0 \mathrm{mV}$ at $2 \mathrm{~cm}$ depin. A similar drop was seen in pr: 7.6 in the upper centimetre and 7.1 at $2 \mathrm{~cm}$ depth and below. In sediments from $\mathrm{Stn} B Z$, both redox potential and $\mathrm{pH}$ were higher as compared to Stn B. The redox potential was about $+200 \mathrm{mV}$ in the upper centimetre and decreased to $+100 \mathrm{mV}$ at $7 \mathrm{~cm}$ depth. The $\mathrm{pH}$ values were uniformly 7.7 to 7.6 in all the analysed layers down to $7 \mathrm{~cm}$ depth (Table 1).

The upper centimetre at Stn BZ consisted mainly of loose silty material and detached leaves, and in the 1 to $4 \mathrm{~cm}$ layer, the root density was high. The content of organic matter that could be retained by a sieve with a mesh size of $1 \mathrm{~mm}$ (roots and leaves) was 10 to 20 fold higher in the upper 1 to $4 \mathrm{~cm}$ layer of Zostera noltiicovered sediment (Stn BZ) than in the same horizons of sediment cores from Stn B (Table 1). The highest amount was found at $4 \mathrm{~cm}$ depth at Stn BZ $25 \mathrm{mg} \mathrm{dw}$ $\mathrm{cm}^{-3}$ ). In the 5 to $6 \mathrm{~cm}$ depth interval, the quantities of retained organic material were similar at both stations

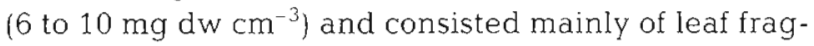

ments. The organic content determined with an $\mathrm{HCN}$ analyser was about $1.2 \mathrm{mmol} \mathrm{C} \mathrm{cm}^{-3}$ in the upper $6 \mathrm{~cm}$ of both sediments (Table 1), except for a peak in the 1 to $2 \mathrm{~cm}$ depth interval at Stn $\mathrm{BZ}\left(1.7 \mathrm{mmol} \mathrm{C} \mathrm{cm}^{-3}\right)$. The $\mathrm{C} / \mathrm{N}$ ratio was lowest in the top centimetre at both stations, ranging from 11.9 at $\operatorname{Stn} B Z$ to 10.2 at $\operatorname{Stn} B$ (Table 1). At Stn BZ, the C/N ratio increased to 15.2 in the root zone, and finally decreased to approximately 13.0 underneath the root layer. At Station $B$, the $C / N$ ratio increased to 13.2 at $4 \mathrm{~cm}$ depth and remained constant below that horizon.

\section{Laboratory experiments}

Expt 1. Under illumination, there was a significant decrease in SRR as a function of duration of the incubation with ${ }^{35} \mathrm{SO}_{4}{ }^{2-}$ in the 0 to $4 \mathrm{~cm}$ layer of the sediment from Stn $B$, whereas no effect could be seen in the 4 to $6 \mathrm{~cm}$ layer (Fig, 1). The most pronounced effect was observed in the upper centimetre, where the mean SRR decreased from $455 \mathrm{nmol} \mathrm{cm}^{-3} \mathrm{~d}^{-1}(0.25 \mathrm{~h}$ incubation in light) to $231 \mathrm{nmol} \mathrm{cm} \mathrm{cm}^{-3} \mathrm{~d}^{-1}$ ( $1 \mathrm{~h}$ incubation) and finally to $87 \mathrm{nmol} \mathrm{cm}^{-3} \mathrm{~d}^{-1}$ ( $5 \mathrm{~h}$ incubation), i.e. a drop to $20 \%$ of the activity from the shortest to the longest incubation. ANOVA also indicated a highly significant reduction of the activity as a function of incubation time $\left(F_{3,8}=34.07, \mathrm{p}<0.0001\right)$. In sediments from Stn BZ, the heterogeneity of the sediment due to the plants caused large standard errors, and although the $0.25 \mathrm{~h}$ incubations seemed to give higher values throughout the root zone than longer incubation times, this was not statistically significant except for the 0 to $1 \mathrm{~cm}$ layer (ANOVA, $F_{3.16}=3.31, \mathrm{p}=0.047$ )

Expt 2. When cores were incubated with ${ }^{35} \mathrm{SO}_{4}{ }^{2-}$ in the dark, the length of the incubation period generally did not have any significant effect on SRR in sediment from Stns $\mathrm{B}$ and $\mathrm{BZ}_{i}$ thus, exhaustion of electron

Table 1. Sediment parameters determined in cores collected at Stns BZ and B

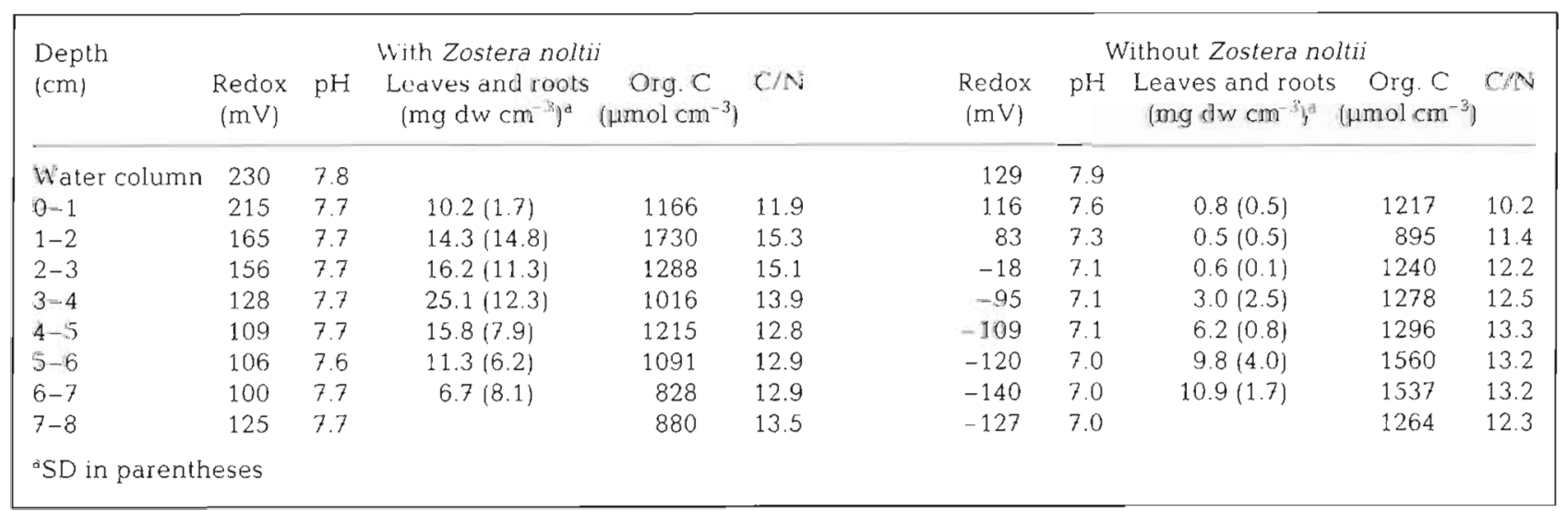




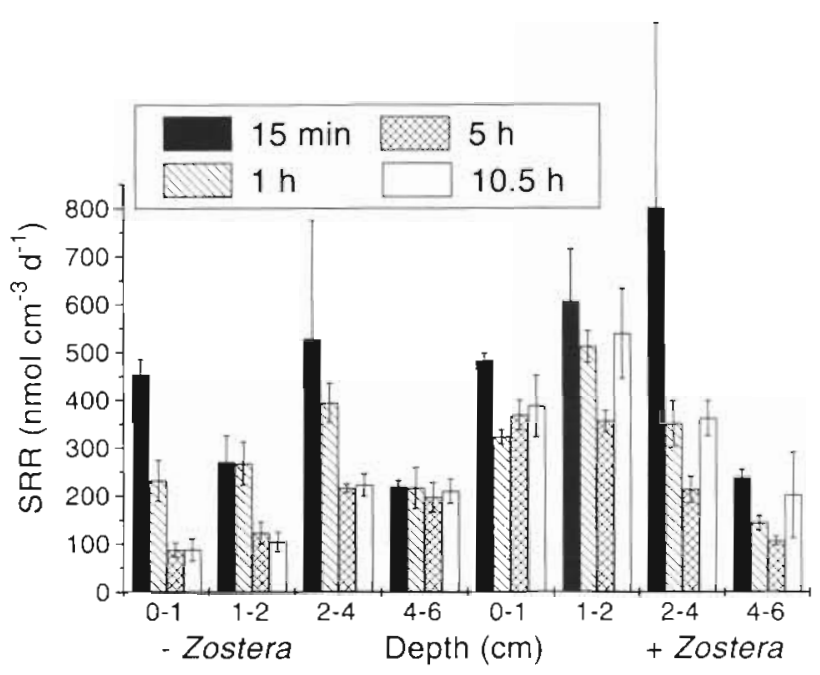

Fig. 1. Mean sulphate reduction rates $( \pm S E)$ in sediment cores with ( $\mathrm{n}=5$ ) and without $(\mathrm{n}=3)$ Zostera noltii, incubated for $0.25,1,5$, and $10.5 \mathrm{~h}$ in the light

donors excreted by the roots as a function of time after darkening did not seem to have an effect, even when the dark incubation was extended to $48 \mathrm{~h}$ (data not shown).

Expt 3. For the laboratory $12 \mathrm{~h}$ light-dark cycle experiment, the sediment cores were all incubated with ${ }^{35} \mathrm{SO}_{4}{ }^{2-}$ for only half an hour to obtain the most realistic SRR. Statistical analysis (ANOVA) of the data showed SRR to be significantly affected by depth $\left(F_{3,283}\right.$ $=23.8, \mathrm{p}<0.0001)$, station $( \pm$ Zostera $)\left(F_{1,283}=114.46\right.$, $\mathrm{p}<0.0001)$, and day/night $\left(F_{1,283}=6.36, \mathrm{p}=0.0122\right)$, whereas no effect of time during day or night could be detected $\left(F_{4,283}=1.02, \mathrm{p}=0.3969\right)$ (Fig. 2). Hence, we pooled all data ignoring the time factor, so that only the effect of depth, station, and day/night on sulphate reduction is considered. It is notable that an increasing number of replicates (15 or 25 in Fig. 2 compared with the normal 3 or 5 replicates in Figs. $1 \& 3$ ) reduced the SE considerably. The rates measured in the surface layer and the root zone of the Zostera noltii bed (down to $4 \mathrm{~cm}$ ) were about double the rates measured outside the vegetated area. Below the root zone, the SRR decreased and the mean rate for light and dark in the 4 to $6 \mathrm{~cm}$ depth interval was significantly lower than the rates determined in the overlying horizons (ca $27 \%$ of the mean rate in the 0 to $1 \mathrm{~cm}$ layer; Tukey $q$-test, $p<$ 0.05). At this depth (4 to $6 \mathrm{~cm}$ ), the mean rates from Stns BZ and B were comparable (188 and $172 \mathrm{nmol}$ $\mathrm{cm}^{-3} \mathrm{~d}^{-1}$ for $\mathrm{BZ}$ and $\mathrm{B}$, respectively). Except for the deepest layers, there was no significant difference between light and dark treatments, and there is no obvious explariaiun fur our finding that the dark rates in the 4 to $6 \mathrm{~cm}$ layer were higher than the rates during illumination. The in situ incubation (see below) showed the opposite trend, and we think that the difference, although statistically significant (Stn BZ: Welch's approximate $t$-test, $t=3.6006, \mathrm{df}=31.1, \mathrm{p}=$ 0.0011 ; Stn B: Welch's approximate $t$-test, $t=2.5691$, $\mathrm{df}=15.5, \mathrm{p}=0.0210$ ), should not be considered real.

\section{In situ experiments}

The light intensity increased from approximately $100 \mu \mathrm{E} \mathrm{m}^{-2} \mathrm{~s}^{-1}$ at the start of the morning incubation (08:00 h) to about $500 \mu \mathrm{E} \mathrm{m} \mathrm{m}^{-2} \mathrm{~s}^{-1}$ at its end. From 10:00 to $11: 30 \mathrm{~h}$, the light intensity was high $(700$ to $1300 \mu \mathrm{E}$ $\mathrm{m}^{-2} \mathrm{~s}^{-1}$ ), but the shading effect of the incoming water during the tide decreased the light intensity reaching the Zostera noltii canopy drastically; it dropped from about $1000 \mu \mathrm{E} \mathrm{m} \mathrm{m}^{-2} \mathrm{~s}^{-1}$ before tidal water input to less than $100 \mu \mathrm{E} \mathrm{m}^{-2} \mathrm{~s}^{-1}$ under a water cover of $50 \mathrm{~cm}$ at the beginning of the mid-day incubation (14:00 h). During the second incubation period, the photon flux never

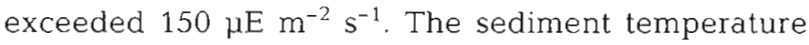
increased in the upper $\mathrm{cm}$ of the sediment from $20.5^{\circ} \mathrm{C}$ at $09: 00 \mathrm{~h}$ to $23.5^{\circ} \mathrm{C}$ at $12: 00 \mathrm{~h}$ and decreased again to $21.5^{\circ} \mathrm{C}$ at $18: 00 \mathrm{~h}$, and the temperature of the overlying water changed correspondingly. No temperature effect was caused by covering of the sediment with the light-impermeable aluminium sheet.

The rates of sulphate reduction in the upper $4 \mathrm{~cm}$ were about 30 to $40 \%$ lower than the corresponding data from the laboratory experiment (Fig. 2), but this can be explained by the use of a $1 \mathrm{~h}$ incubation period with radiotracer, which underestimates the SRR (Fig. 1). A much higher SRR was found in the upper $1 \mathrm{~cm}$ at noon ( $510 \mathrm{nmol} \mathrm{cm}^{-3} \mathrm{~d}^{-1}$ ) as compared to the morning (268 nmol cm${ }^{-3} \mathrm{~d}^{-1}$ ) and afternoon (254 nmol $\mathrm{cm}^{-3} \mathrm{~d}^{-1}$ ) values (Tukey $q$-test, $\mathrm{p}<0.05$ ), whereas no significant effect of time was observed in deeper layers

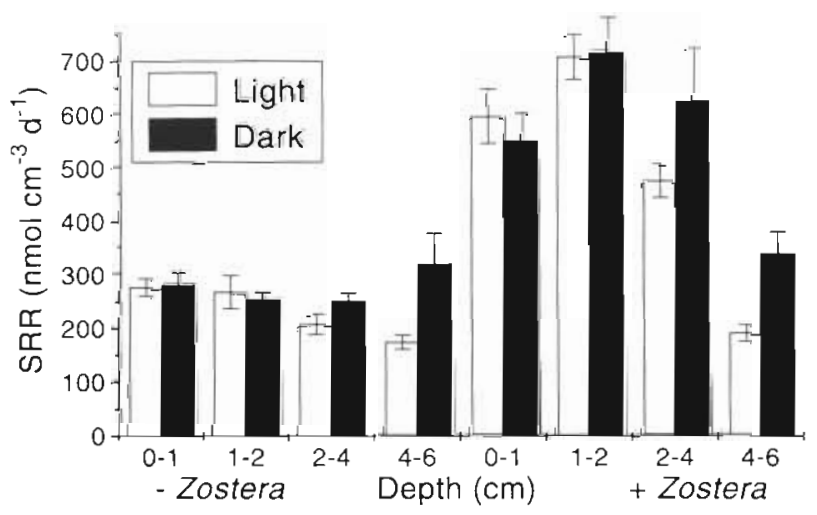

Fig. ? Mean silphate reduction rates ( $+S E)$ in sodimont corcs $(n=25)$ with and without $(n=15)$ Zostera noltii. For sulphate reduction rate determination, all samples were incubated for $0.5 \mathrm{~h}$ in the dark or light 


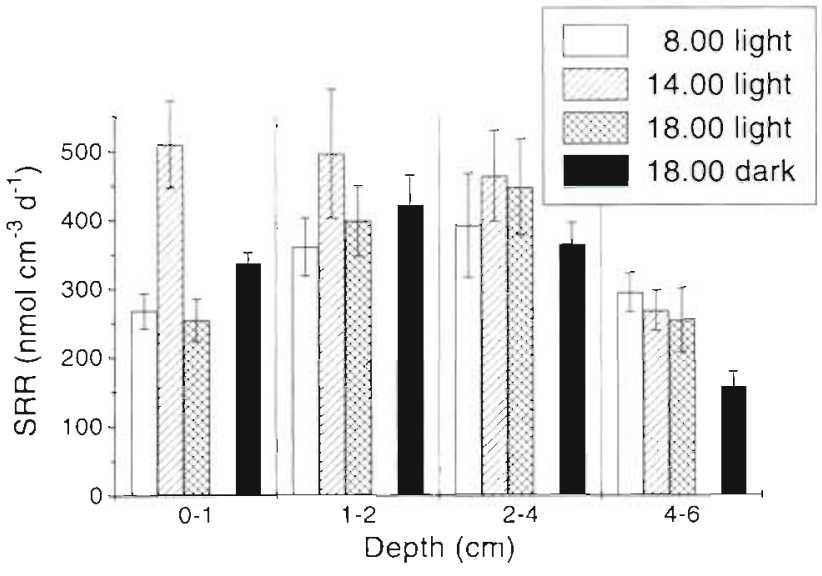

Fig. 3. In situ sulphate reduction rates $( \pm \mathrm{SE}, \mathrm{n}=5)$ in sediment with Zostera noltii. All samples were incubated for $1 \mathrm{~h}$ at different times of the day. The dark incubation was carried out in sediment covered by a light-impermeable aluminum sheet

(Fig. 3). The stimulation in the upper layer may have been due to a decreasing photosynthetic activity of the benthic microalgae community, lowering the penetration depth of oxygen and thereby lowering the reoxidation of reduced inorganic sulfur compounds (Moeslund et al. 1994 and Fig. 1 in this paper). Additionally, the $3^{\circ} \mathrm{C}$ increase in temperature could have been responsible for approximately 20 to $30 \%$ of the stimulation (Isaksen \& Jørgensen 1994, Isaksen \& Jørgensen 1996). For all the layers down to $4 \mathrm{~cm}$, the dark values were similar to the mean of the light values. In the 4 to $6 \mathrm{~cm}$ layer, the rate in the dark was only $60 \%$ of those found in the light, which is exactly the opposite of the laboratory experiment results.

\section{DISCUSSION}

The presence of Zostera noltii obviously had a stimulating effect on the rates of sulphate reduction (Figs. 1, $2 \& 3$ ). The rates in the 0 to $4 \mathrm{~cm}$ layer with the roots were about twice as high as in sediments free of plant cover, whereas no significant difference could be found between sediments from Stn B and BZ below the root zone. The shape of the SRR profile (Stn BZ) is in good agreement with the distribution pattern of the sulphate reducer community, which has highest population densities $\left(6 \times 10^{7} \mathrm{~cm}^{-3}\right)$ in the 1.0 to $1.5 \mathrm{~cm}$ depth interval (B. Schaub \& $H$. van Gemerden pers. comm.)

Budgets for heterogeneous environments such as vegetated sediments should only be made with a large number of replicates. In this study we have analysed more replicates than in any previous study that we know of, but even so there were limitations concerning the statistical evaluation of data obtained in some of our experiments.

\section{Reoxidation of hydrogen sulphide}

In Expt 1. (Fig. 1) we investigated the influence of incubation time with radiotracer on the measured SRR. There was a significant decline of the measured SRR with time in the unvegetated sediment down to $4 \mathrm{~cm}$ depth, and although a similar trend was observed in the vegetated sediment, the heterogeneity in the analysed cores was so large that we do not have a statistically firm reason to argue that the same drop in activity occurred here. The drop in activity with incubation time must have been due to a reoxidation of sulphide by oxidised inorganic compounds such as $\mathrm{Fe}(\mathrm{OH})_{3}$ and $\mathrm{MnO}_{2}$, and in the vegetated sediments possibly also by oxygen excreted trom the roots (Iizumi et al. 1980, Sand-Jensen et al. 1982, Smith et al. 1984. Caffrey \& Kemp 1991). As the vegetated sediments did not have any sulphide smell and were found by redox potential analysis to be more oxidised than the unvegetated sediments, the reoxidation mechanism must have been at least as efficient as in the unvegetated sediments, but this was blurred by the heterogeneity. Below $4 \mathrm{~cm}$ depth, there seemed to be only little reoxidation at both Stn $B$ and $B Z$.

The surface sediments in Arcachon were very rich in oxidised iron minerals (L. Stal pers. comm.), but as oxidised iron occurs as highly insoluble compounds, and as oxygen penetrates only to very shallow depths by diffusion through the regular sediment surface, reoxidation can only be mediated either by local oxygen intrusion due to faunal or plant activity, or by more widespread resuspension of sediments (especially non-vegetated sediments) during high winds (Revsbech et al. 1980). The high iron content is ecologically very important as it serves as a redox buffer in periods when the oxygen supply to the sediment cannot match the need for reoxidation, especially of sulphide, but for our measurements the high reoxidation rates of sulphide represent a significant methodological problem. We know that the rates measured after 15 min incubations were higher than after longer incubations, but we do not know how much higher the rates would have been if we could have totally avoided reoxidation. To obtain the data shown in Fig. 2, we incubated the cores for only half an hour with radiotracer, but that is the shortest incubation time that allowed us to process the large series of cores. During the field experiment, where injections had to be made vertically, we even had to use $1 \mathrm{~h}$ incubations. 


\section{Diurnal cycle of sulphate reduction}

From the data presented in Figs. 2 \& 3, no impact of plant photosynthetic activity can be seen on the SRR in the root zone. The rates in the light and in the dark were very similar. This is in contrast to studies on tropical seagrass beds in Jamaica and northern Australia, where a stimulation was found during illumination (Moriarty et al. 1985, Pollard \& Moriarty 1991, Blackburn et al. 1994). It has been proposed (Blackburn et al. 1994) that the stimulation by light was due to excretion of photosynthates, and this conclusion was supported by the finding that in a meadow of Halodule beaudettiSRR decreased to very low levels after 5 to $10 \mathrm{~h}$ in the dark. In oligotrophic tropical carbonate sediments, such exudates may constitute a much larger fraction of the total amount of electron donors available for the bacterial population than was the case in the eutrophic Arcachon sediments. It is also possible that Zostera noltii excrete much less organic carbon than $H$. beaudetti, or that the exudates are more heavily degradable. Excretion of organic matter from the roots is well documented for a number of marine macrophytes (Penhale \& Smith 1977. Wetzel \& Penhale 1979, Moriarty et al. 1986), but although we incubated sediment cores for up to $48 \mathrm{~h}$ in darkness, no decrease in SRR could be detected (data not shown).

The large difference in SRR between sediments from Stns B and BZ (e.g. Fig. 2) indicated that there was more degradable organic matter available in the upper $4 \mathrm{~cm}$ of sediment at Stn BZ. Interestingly, the content of organic carbon present as determined by $\mathrm{HCN}$ analysis was approximately the same at both stations (about $1.2 \mathrm{mmol}$ $\mathrm{cm}^{-3}$; Table 1), whereas the content of larger pieces of organic material such as roots and partly degraded leaves was very different. Fresh and easily degradable material may give rise to higher activity of heterotrophic fermentative bacteria and thereby to a higher production of fermentation products such as hydrogen and volatile fatty acids, which are the most important substrates for sulphate-reducing bacteria (Sørensen et al. 1981, Widdel 1988). The higher rates measured at $S \operatorname{tn} B Z$ were therefore most likely due to the quality rather than quantity of the organic carbon present.

The data from the laboratory experiments were supported well by the in situ experiments. The field experiment served as an extra control and also to elucidate whether very high light intensities had an effect. There was no effect of light regime on SRR in the root horizon from 1 to $4 \mathrm{~cm}$ depth.

\section{CONCLUSIONS}

The rate of sulphate reduction in the sediment was highly stimulated by the presence of Zostera noltii throughout the upper 0 to $4 \mathrm{~cm}$ layer, which was heavily infiltrated by roots. No difference between the rate of sulphate reduction in vegetated and non-vegetated sediment could be detected below the root zone. There was no difference between the rates of sulphate reduction in the root zone during illumination and darkness, and direct utilization by sulphate-reducing bacteria of root exudates originating from photosynthetic activity may therefore be less important than low-molecularweight organic molecules produced by microbial hydrolysis of macromolecules. The results stress the importance of keeping the incubation time short when measuring sulphate reduction in relatively oxidised sediments, as $15 \mathrm{~min}$ incubations with radiotracer gave up to 6 times higher rates of sulphate reduction than incubation for several hours.

Acknowledgements. We thank Prof. Caumette and the staff of the marine station in Arcachon for their hospitality during the sampling campaigns. The authors are indebted to Dr Niels Peter Revsbech for support. We thank Tove Wiegers for her skilful assistance during the first sampling campaign, Dr Hans van Gemerden for placing Redox electrodes at our disposal and Bo Sommerlund for his data program for random placement of the sediment cores. We thank Dr Bo Thamdrup and 3 anonymous referees for reviewing the manuscript. Mai Faurschou Isaksen was supported by a grant of the Danish Natural Science Research Council. The study was financed by a joint EU project on 'Coastal Lagoon Eutrophication and ANaerobic processes (CLEAN)', contract number EV5VCT92-008.

\section{LITERATURE CITED}

Auby I (1991) Contribution à l'étude des herbiers de Zostera noltii dans le Bassin d'Arcachon: dynamique, production et dégradation, macrofaune associée. PhD thesis, Univ Bordeaux I

Blackburn Tł I, Nedwell DB, Wiebe WJ (1994) Active mineral cycling in a Jamaican seagrass sediment. Mar Ecol Prog Ser 110:233-239

Caffrey JM, Kemp WM (1990) Nitrogen cycling in sediments with estuarine populations of Potamogeton perfoliatus and Zostera marina. Mar Ecol Prog Ser 66:147-160

Caffrey JM, Kemp WM (1991) Seasonal and spatial patterns of oxygen production, respiration and root rhizome release in Potamogeton perfoliatus L. and Zostera marina L. Aquat Bot 40:109-128

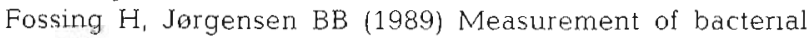
sulfate reduction in sediments: evaluation of a single-step chromium reduction method. Biogeochemistry 8:205-222

Iizumi H. Hattori A, McRoy CP (1980) Nitrate and nitrite in interstitial waters of eelgrass beds in relation to the rhizosphere. J Exp Mar Biol Ecol 47:191-201

Isaksen MF, Jorgensen BB (1994) Thermophilic sulfate-reducing bacteria in cold marine sediment. FEMS Microbiol Ecol 14:1-8

Isaksen MF, Jargensen BD (1006) The aduptution of $p 5 \ddot{y}$ chrophilic and psychrotrophic sulfate reducing bacteria to permanently cold marine environments. Appl Environ Microbiol 62:408-414 
Jørgensen BB (1977) The sulfur cycle of a coastal marine sediment (Limfjorden, Denmark). Limnol Oceanogr 22: $814-832$

Jørgensen BB (1994) Sulfate reduction and thiosulfate transformations in a cyanobacterial mat during a diel oxygen cycle. FEMS Microbiol Ecol 13:303-312

Koepfler ET, Benner R, Montagna PA (1993) Variability of dissolved organic-carbon in sediments of a seagrass bed and an unvegetated area within an estuary in Southern Texas. Estuaries 16:391-404

Moeslund L, Thamdrup B, Jergensen BB (1994) Sulfur and iron cycling in a coastal sediment: radiotracer studies and seasonal dynamics. Biogeochemistry 27:129-152

Moriarty DJW, Boon PI, Hansen JA, Hunt WG, Poiner IR, Pollard PC, Skyring GW, White DC (1985) Microbial biomass and productivity in seagrass beds. Geomicrobiol J 4:21-51

Moriarty DJW, Iverson RL, Pollard PC (1986) Exudation of organic carbon by the seagrass Halodule wrightii Aschers. and its effect on bacterial growth in the sediment. J Exp Mar Biol Ecol 96:115-126

Oremland RS, Taylor BF (1977) Diurnal fluctuations of $\mathrm{O}_{2}, \mathrm{~N}_{2}$ and $\mathrm{CH}_{4}$ in the rhizosphere of Thalassia testudinum. Limnol Oceanogr 22:565-570

Penhale PA, Smith WO (1977) Excretion of dissolved organic carbon by eelgrass (Zostera marina) and its epiphytes. Limnol Oceanogr 22:400-407

Pollard PC, Koike I, Mukai H, Robertson AI (eds) (1993) Tropical seagrass ecosystems; structure and dynamics in the Indo-West Pacific. Aust J Mar Freshwat Res 44

Pollard PC, Moriarty DJW (1991) Organic-carbon decomposi-

This article was submitted to the editor tion, primary and bacterial productivity, and sulfate reduction, in tropical seagrass beds of the Gulf of Carpentaria Australia. Mar Ecol Prog Ser 69:149-159

Revsbech NP, Jørgensen BB, Blackburn TH (1980) Oxygen in the sea bottom measured with a microelectrode. Science 207:1355-1356

Robert R, Guillocheau N, Collos Y (1987) Hydrobiological parameters during an annual cycle in the Arcachon Basin. Mar Biol 95:631-640

Sand-Jensen K, Prahl C, Stokholm H (1982) Oxygen release from roots of submerged aquatic macrophytes. Oikos 38 $349-354$

Smith RD, Dennison WC, Alberte RS (1984) Role of seagrass photosynthesis in root aerobic processes. Plant Physiol 74 $1055-1058$

Sorokin YI (1962) Experimental investigation of bacterial sulfate reduction in the black sea using ${ }^{35} \mathrm{~S}$. Microbiology 31 : $329-335$

Sørensen J, Christensen D, Jørgensen BB (1981) Volatile fatty acids and hydrogen as substrates for sulfate reducing bacteria in anaerobic marine sediment. Appl Environ Microbiol 42:5-11

Wetze! RG, Penhale PA. (1979) Transport of carbon and excretion of dissolved organic carbon by leaves and roots/rhizomers in seagrasses and their epiphytes. Aquat Bot 6 $149-158$

Widdel F (1988) Microbiology and ecology of sulfate- and sulfur-reducing bacteria. In: Zehnder AJB (eds) Biology of anaerobic microorganisms, Vol 1. John Wiley \& Sons, Inc, New York, p 469-585

Manuscript first received: January 30, 1995

Revised version accepted: February 15, 1996 